TECHNICAL PROGRESS REPORT, FEBRUARY 2000 TO SEPTEMBER 2000:

\title{
EXPERIMENTAL EVALUATION OF CHEMICAL SEQUESTRATION OF CARBON DIOXIDE IN DEEP AQUIFER MEDIA - PHASE II
}

\author{
Contract No. DE-AC26-FT40418 \\ Modification A005 \\ Prepared for: \\ Charles Byrer \\ NETL Project Officer \\ U.S. Department of Energy \\ National Energy Technology Laboratory \\ P.O. Box 880 \\ Morgantown, WV 26507-0880
}

Prepared by:

Neeraj Gupta

Bruce Sass

Jennifer Ickes

Battelle Memorial Institute

505 King Avenue

Columbus, Ohio 43201

November 28, 2000 
This report was prepared by Battelle as an account of work sponsored by an agency of the United States Government. Neither the United States Government nor any agency thereof, nor any of their employees, nor Battelle makes any warranty, express or implied, or assumes any legal liability of responsibility for the accuracy, completeness, or usefulness of any information, apparatus, product, or process disclosed, or represents that its use would not infringe privately owned rights. Reference herein to any specific commercial product, process, or service by trade name, trademark, manufacturer, or otherwise does not necessarily constitute or imply its endorsement, recommendation, or favoring by Battelle, the United States Government or any agency thereof. The views and opinions of authors expressed herein do not necessarily state or reflect those of the United States Government or any agency thereof. 


\begin{abstract}
In 1998 Battelle was selected by the U.S. Department of Energy's (DOE) National Energy Technology Laboratory (NETL) under a Novel Concepts project grant to continue Phase II research on the feasibility of carbon dioxide $\left(\mathrm{CO}_{2}\right)$ sequestration in deep saline formations. The focus of this investigation is to conduct detailed laboratory experiments to examine factors that may affect chemical sequestration of $\mathrm{CO}_{2}$ in deep saline formations. Reactions between sandstone and other geologic media from potential host reservoirs, brine solutions, and $\mathrm{CO}_{2}$ are being investigated under high-pressure conditions. Some experiments also include sulfur dioxide $\left(\mathrm{SO}_{2}\right)$ gases to evaluate the potential for co-injection of $\mathrm{CO}_{2}$ and $\mathrm{SO}_{2}$ related gases in the deep formations. In addition, an assessment of engineering and economic aspects is being conducted.

This current Technical Progress Report describes the status of the project as of September 2000. The major activities undertaken during the quarter included several experiments conducted to investigate the effects of pressure, temperature, time, and brine composition on rock samples from potential host reservoirs. Samples (both powder and slab) were taken from the Mt. Simon Sandstone, a potential $\mathrm{CO}_{2}$ host formation in the Ohio, the Eau Claire Shale, and Rome Dolomite samples that form the caprock for Mt. Simon Sandstone. Also, a sample with high calcium plagioclase content from Frio Formation in Texas was used. In addition, mineral samples for relatively pure Anorthite and glauconite were experimented on with and without the presence of additional clay minerals such as kaolinite and montmorillonite. The experiments were run for one to two months at pressures similar to deep reservoirs and temperatures set at $50^{\circ} \mathrm{C}$ or $150^{\circ} \mathrm{C}$. Several enhancements were made to the experimental equipment to allow for mixing of reactants and to improve sample collection methods. The resulting fluids (gases and liquids) as well as the rock samples were characterized to evaluate the geochemical changes over the experimental period. Preliminary results from the analysis are presented in the report. More detailed interpretation of the results will be presented in the technical report at the end of Phase II.
\end{abstract}




\section{CONTENTS}

ABSTRACT

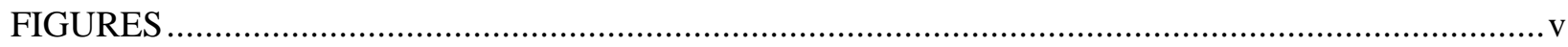

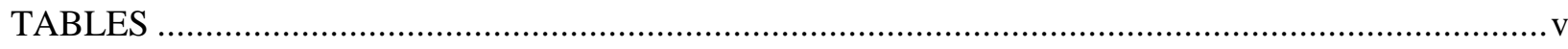

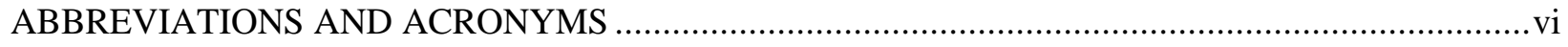

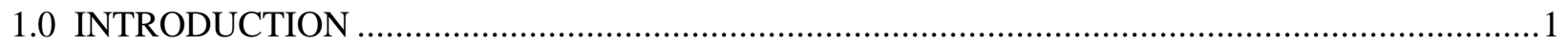

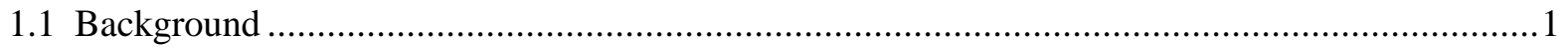

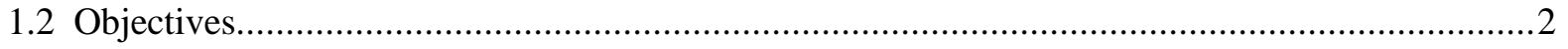

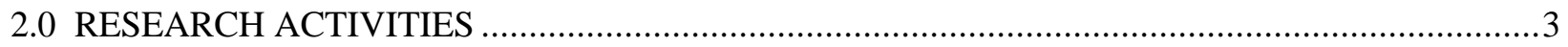

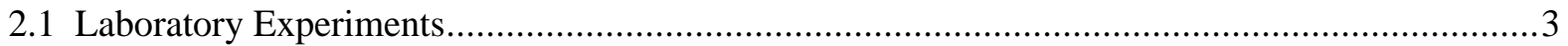

2.1.1 Preparation of Brine Solution and Gas Mixture ...........................................................

2.1.2 Laboratory Setup for High-Pressure Experiment .......................................................

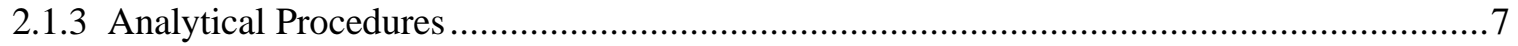

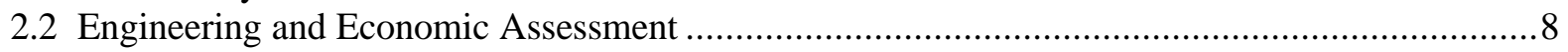

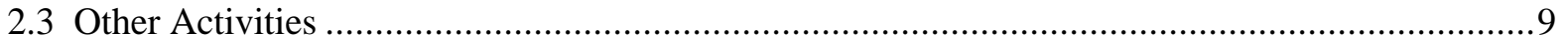

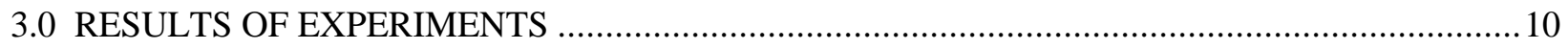

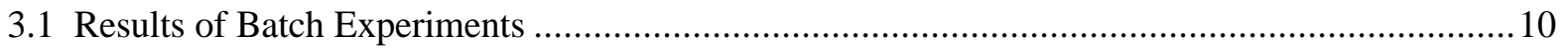

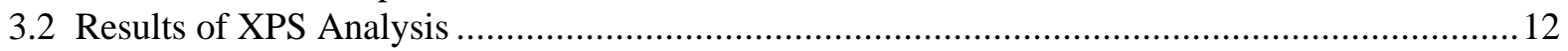

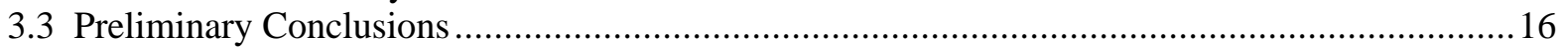

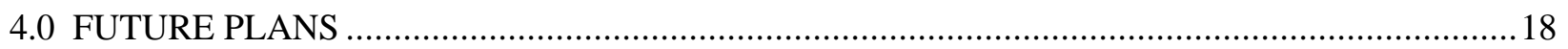

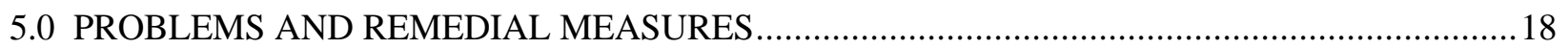

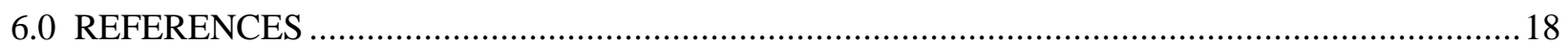




\section{FIGURES}

Figure 2-1. Schematic Drawing of Pressure Vessel...................................................................... 6

Figure 2-2. Photograph Showing Pressure Vessels Used In Experiments .........................................6

Figure 3-1. Portion of the XPS Spectrum for Unreacted and Reacted Anorthite .................................. 13

Figure 3-2. Concentrations of Sodium and Calcium for Ideal $\mathrm{An}_{90}$ and Experimental Specimens........... 14

Figure 3-3. Concentrations of Aluminum and Silicon for Ideal $A_{n_{90}}$ and Experimental Specimens ........15

Figure 3-4. Anorthite Content Based on Sodium and Calcium Concentrations for an Ideal System (lines) and Experimental Specimens (symbols)

\section{TABLES}

Table 2-1. Sample Origin and Quantity Used in Experiments ...........................................................

Table 2-2. General Composition of Synthetic Brine Stock Solution ...................................................

Table 2-3. Actual Composition of Brines Solutions used in Experiments............................................5

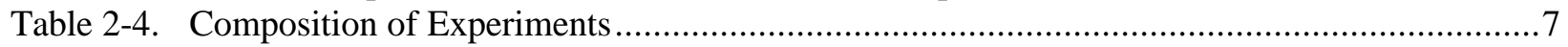

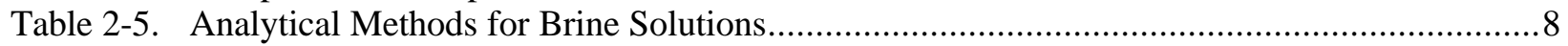

Table 2-6. Cases Used to Explore Cost Sensitivity of Transportation/Sequestration..............................9

Table 3-1. Concentrations of Dissolved Species (mg/L) in Brine after Reaction with Rock Samples for Experiment 2

Table 3-2. Concentrations of Dissolved Species (mg/L) in Brines after Reaction with Rock Samples for Experiment 3

Table 3-3. Composition of Gas Phase at End of Experiments (\% by Volume)..................................12

Table 3-4. Results of XPS Analysis of Anorthite in Percent Peak Area.............................................13

Table 3-5. Results of XPS Analysis of Glauconite in Percent Peak Area .......................................... 16 


\section{ABBREVIATIONS AND ACRONYMS}

BDL below detection limit

BEG (Texas) Bureau of Geology

$\mathrm{CO}_{2} \quad$ carbon dioxide

DOE U.S. Department of Energy

EPA U.S. Environmental Protection Agency

EDS energy dispersive spectroscopy

ESCA electron spectroscopy for chemical analysis

EXAFS extended $x$-ray absorption fine structure

ICP/MS inductively-coupled plasma/mass spectrometry

IGCC intergrated coal gasification combined cycle

NA not available

NETL National Energy Technology Laboratory

ND not detectable

ORP oxidation-reduction potential

PC pulverized coal without flue gas desulphurization

PC/FGD pulverized coal with flue gas desulphurization

ppm parts per million

psi pounds per square inch

SEM scanning electron microscopy

SIMS secondary ion mass spectrometry

TOC total organic carbon

XRD $\quad \mathrm{x}$-ray diffractometry

XPS $\quad \mathrm{x}$-ray photoelectron spectroscopy 


\subsection{INTRODUCTION}

In 1998 Battelle was selected by the U.S. Department of Energy's (DOE) National Energy Technology Laboratory (NETL) under a Novel Concepts project grant to pursue Phase I research on the feasibility of carbon dioxide $\left(\mathrm{CO}_{2}\right)$ sequestration in deep saline formations. The focus of this investigation was to conduct preliminary laboratory experiments to examine factors that may affect chemical sequestration of $\mathrm{CO}_{2}$ in deep saline formations. Reactions between sandstone from a potential host reservoir, synthetic brine, and compressed $\mathrm{CO}_{2}$ were investigated. The findings of the experiments along with preliminary cost estimates for the technology were presented in a topical report for Phase I of this project (Sass et al., 1999). In July 1999, Battelle was awarded the contract modification (DE-AC26-FT40418, Modification A005) to continue these experiments into a more elaborate Phase II. The Period of Performance for this phase is from July 30, 1999 to May 30, 2001. The NETL Project Manager for this project is Mr. Charles Byrer.

This current report is an interim Technical Progress Report mainly covering the activities from February 1, 2000 to September 29, 2000. The report summarizes mainly the laboratory activities undertaken during the reporting period as well as the progress made on engineering and economic aspects of $\mathrm{CO}_{2}$ sequestration in deep saline formations.

\subsection{Background}

Disposal of $\mathrm{CO}_{2}$ in a dense, supercritical phase in deep saline formations is considered to be one of the most promising long-term options for $\mathrm{CO}_{2}$ sequestration. Deep saline formations are considered to be among the largest and most widely available potential reservoirs for long-term to permanent storage. Usable formations are known to exist both terrestrially and under the oceans. Both formation types appear to have an abundant disposal capacity. Terrestrial formations are located in close proximity to major point sources of $\mathrm{CO}_{2}$ emissions such as fossil-fuel power plants, which has the benefit of reducing transportation costs. For example, Bergman and Winter (1995) estimate that $65 \%$ of U.S. power plant $\mathrm{CO}_{2}$ emissions can be injected into nearby deep formations without the need for long pipelines. However, capacity estimates for global storage potential range widely because of uncertainties in the estimation methods and underlying geologic data. Subsea formations offer the potential advantage of being located away from areas of human contact. Currently, an offshore facility for the deep injection of $\mathrm{CO}_{2}$ exists at Norway's Sleipner West facility in the North Sea.

Geologic disposal of $\mathrm{CO}_{2}$ involves finding geologically suitable formations for sequestering large amounts of $\mathrm{CO}_{2}$ for a long period, without a significant environmental risk and at a reasonable cost. Suitable formations are deep, regionally extensive, filled with saline waters, and separated from freshwater and other formations of economic interest by low permeability caprock. For $\mathrm{CO}_{2}$ disposal applications, a minimum depth of about 800 meters is required to maintain the pressure and temperature for retaining $\mathrm{CO}_{2}$ in a dense, supercritical phase. Other siting criteria involve making detailed evaluations of geologic, hydrogeologic, geochemical, and seismic issues. Because of the multitude of hydrogeologic and geochemical processes involved, the feasibility of $\mathrm{CO}_{2}$ disposal needs to be evaluated at several different spatial (such as pore scale, injection well scale, and formation scale) and temporal (short-term and longterm) scales. Many of these aspects were discussed in the Phase I Topical Report for the current project (Sass et al., 1999). Phase II of the project focuses mainly on understanding the geochemical aspects of $\mathrm{CO}_{2}$ sequestration in geologic media. In addition, a more detailed assessment of economics of $\mathrm{CO}_{2}$ sequestration in deep aquifers is being conducted. 


\subsection{Objectives}

The main objective of the Phase II effort is to investigate mineralogical reactions in a saline formation in greater detail than was possible in Phase I. In the current effort, experiments are being conducted using rock samples from different potential host reservoirs and overlying rocks. These experiments will investigate the effects of pressure, temperature, time, and brine composition on the mineralogy of the rock. Pressure is a key variable because it controls the equilibrium concentration of $\mathrm{CO}_{2}$ in the brine and therefore the ultimate amount of $\mathrm{CO}_{2}$ available for permanent $\mathrm{CO}_{2}$ sequestration. Variations in temperature and time will be explored to the extent feasible because they affect reaction kinetics, which could have important consequences on a full-scale injection operation. For example, if the reactions are too slow, the potential for leakage of $\mathrm{CO}_{2}$ into overlying formations may increase. On the other hand, fast reaction rates may adversely affect the porosity and permeability of a formation near the injection well by diminishing injectivity and therefore shortening the lifetime of the injection well.

Experiments also will be conducted to test the effects of sulfur compounds on the system. For example, carbonyl sulfide (COS), sulfur oxides $\mathrm{SO}_{2}$ and $\mathrm{SO}_{3}$, and hydrogen sulfide $\left(\mathrm{H}_{2} \mathrm{~S}\right)$ are important byproducts of coal combustion, and their presence in a compressed gas stream is a significant concern to the carbon sequestration process. Therefore, additional tests will be performed using typical concentrations of one or more of these compounds in the gas phase. Detailed characterization will be performed after the experiments are completed to determine if any of the sulfur compounds impede carbon sequestration or produce byproducts that may potentially impact the sequestration process. Concern of sulfate content arises because under certain conditions, high sulfate concentrations in the brine could lead to gypsum precipitation and promote premature clogging.

At the end of the experiments a detailed technical report will be submitted. In addition, a report on the economic and engineering aspects will also be submitted. Recommendations and work plan for Phase III will be prepared and submitted to NETL for consideration. 


\subsection{RESEARCH ACTIVITIES}

The experimental activities include procurement of rock/mineral samples and reactive gases, preparation of brine solutions, preparation of experimental apparatus such as high-pressure reaction vessels and shaker tables, and conduction of experiments. The reactive materials (solids, liquids, and gases) were characterized extensively before and after the experiments. Some of these activities are summarized below.

\subsection{Laboratory Experiments}

Table 2-1 lists all of the experiments conducted as of October 2000. Most of the rock samples needed for the laboratory experiments represent potential host and caprock formations in the Midwestern United States, including the Mt. Simon Sandstone and overlying Eau Claire Shale and Rome Dolomite formations. These samples were obtained from the rock core repository maintained by the Ohio Geological Survey. The Texas Bureau of Geology (BEG) provided Battelle with a sample with high feldspar content from the Frio Formation in southern Texas, which is a potential host reservoir for $\mathrm{CO}_{2}$ sequestration. The potentially high calcium feldspar content in this sample will be used to evaluate formation of calcite by feldspar dissolution in the presence of $\mathrm{CO}_{2}$, as a mechanism for permanent carbon sequestration. Additionally, mineral samples were obtained for Anorthite, Glauconite, and clay minerals to evaluate potential reactions in relatively pure minerals.

Table 2-1. Sample Origin and Quantity Used in Experiments

\begin{tabular}{|c|c|c|c|c|}
\hline $\begin{array}{c}\text { Experiment } \\
\text { No. }\end{array}$ & Core No./Sample Name & $\begin{array}{c}\text { Core } \\
\text { Depth (ft) }\end{array}$ & Location & $\begin{array}{c}\text { Mass of } \\
\text { Sample (g) }\end{array}$ \\
\hline $1 \mathrm{~A}$ & Core No. 2,843, Mt. Simon Sst. & 2,974 & Butler County, Ohio & 71.1 \\
\hline $1 \mathrm{~B}$ & Core No. 2,843, Mt. Simon Sst. & 2,980 & Butler County, Ohio & 66.7 \\
\hline $1 \mathrm{C}$ & Core No. 2,843, Mt. Simon Sst. & 2,985 & Butler County, Ohio & 34.1 \\
\hline 1D & Core No. 2,958, Mt. Simon Sst. & $5,532.3$ & Scioto County, Ohio & 38.4 \\
\hline $2 \mathrm{~A}$ & Core No. 2,838, Rome Dolomite & 5,580 & Ashtabula County, Ohio & 94.56 \\
\hline $2 \mathrm{~B}$ & Glauconite & NA & Unreported & 81.82 \\
\hline $2 \mathrm{C}$ & Anorthite & NA & Japan & 80.77 \\
\hline 2D & TBS Well 149, Frio Formation & $3,967.3$ & Rincon Field, S. Texas & 79.08 \\
\hline $3 \mathrm{~A}$ & Core No. 645, Eau Claire Shale (Slab) & 3,071 & Logan County, Ohio & 1.9576 \\
\hline $3 B$ & Core No. 645, Mt. Simon Sst. (Slab) & 3,140 & Logan County, Ohio & 2.2233 \\
\hline $3 \mathrm{C}$ & Anorthite (Slab) & NA & Japan & 1.262 \\
\hline $3 \mathrm{D}$ & Core No. 2,838, Rome Dolomite (Slab) & 5,580 & Ashtabula County, Ohio & 1.0363 \\
\hline $3 \mathrm{E}$ & Core No. 2,838, Mt. Simon Sst. (Slab) & 5,911 & Ashtabula County, Ohio & 2.3348 \\
\hline $3 \mathrm{~F}$ & TBS Well 149, Frio Formation (Slab) & $3,967.3$ & Rincon Field, S. Texas & 0.5617 \\
\hline $3 \mathrm{G}$ & $\begin{array}{c}\text { Anorthite } \\
\end{array}$ & NA & Japan & 78.0158 \\
\hline $3 \mathrm{H}$ & Glauconite & NA & Unreported & 76.8925 \\
\hline $4 \mathrm{~A}$ & Core No. 645, Eau Claire Shale & 3,071 & Logan County, Ohio & 44.59 \\
\hline $4 \mathrm{~B}$ & Core No. 645, Mt. Simon Sst. & 3,140 & Logan County, Ohio & 44.46 \\
\hline $4 \mathrm{C}$ & Core No. 779, Eau Clare Shale & 3,379 & Fayette County, Ohio & 45.14 \\
\hline 4D & Core No. 2,580, Rome Dolomite & 2,726 & Seneca County, Ohio & 25.88 \\
\hline $5 \mathrm{~A}$ & Anorthite/Kaolinite & NA & Commercial & $50 / 30$ \\
\hline $5 B$ & Anorthite/ Montmorillonite & NA & Commercial & $50 / 30$ \\
\hline
\end{tabular}

NA $=$ Not available. 
The powder samples were finely ground in a jar mill and sieved to recover the 38-106 $\mu \mathrm{m}$ size fraction (Table 2-1). After sieving, the samples were washed in deionized water with ultrasonic agitation to remove both excess salt and extremely fine and possibly amorphous material that may have been produced by grinding. It is desirable to remove amorphous material, because it may form different products than would be formed from crystalline reactants. The samples then were vacuum dried at $40^{\circ} \mathrm{C}$ for 7 hours. A portion of each of the samples was saved for chemical and mineralogical analysis.

For Experiment 3, thin slabs cut from six rock specimens were reacted. The slabs were cut to expose fresh surfaces using a diamond saw and then polished on a lapidary wheel. Each slab was cut in pairs, so that one portion could be reacted in brine and $\mathrm{CO}_{2}$, as in previous experiments, and the other slab saved in its original state. After the experiments were completed, both the reacted and unreacted slabs were examined using a microprobe. In addition to the slabs, two powder samples, Anorthite and Glauconite, were rerun in the third set of experiments.

\subsubsection{Preparation of Brine Solution and Gas Mixture}

A stock brine solution was prepared with composition similar to Mt. Simon Sandstone brines that have been sampled in the deep wells in Ohio (see Table 2-2). The actual concentration of the different batches of diluted brines was determined by chemical analysis (Table 2-3). Calculations were made to determine the optimal ratio of rock, brine, and $\mathrm{CO}_{2}$ for conducting the experiments. High-purity $\mathrm{CO}_{2}$ and nitrogen gas cylinders were procured for use in the experiments. The oxygen content of these gases is required to be less than 5 parts per million (ppm), to prevent oxidation or iron and other redox-sensitive elements. For the second set of experiments the samples were reacted for 30 days at $50^{\circ} \mathrm{C}$. The $\mathrm{CO}_{2}$ content of the gas was 600 pounds per square inch (psi) and the final pressure was brought to 2,000 psi with $\mathrm{N}_{2}$ gas.

Table 2-2. General Composition of Synthetic Brine Stock Solution

\begin{tabular}{||c|ccccccc||}
\hline Component & Na & K & Mg & Ca & Cl & Alkalinity & SO $_{4}$ \\
\hline \hline Concentration $(\mathrm{mg} / \mathrm{L})$ & 22,666 & 794 & 1,286 & 7,840 & 61,200 & 23 & 1,080 \\
\hline
\end{tabular}

For Experiment 3, the $\mathrm{CO}_{2}$ content of the gas phase was increased to $2,500 \mathrm{psi}$, compared to $600 \mathrm{psi}$ in the previous sets of experiments. The temperature of the experiments also was increased from $50^{\circ} \mathrm{C}$ to $150^{\circ} \mathrm{C}$. By using a higher partial pressure, more $\mathrm{CO}_{2}$ could be dissolved into the brine, which was expected to increase the extent of the reaction and enhance the product yields. This enhancement was needed, because the polished slabs have less total surface area than the powdered samples and were expected to react at a slower rate. To achieve the elevated $\mathrm{CO}_{2}$ pressure, a tank fitted with an eductor tube was ordered from a supply company. The eductor tube allows liquid $\mathrm{CO}_{2}$ to be transferred to the reaction vessel.

For Experiment 4, four powder samples (Table 2-1) were reacted for approximately 40 days at $150^{\circ} \mathrm{C}$. The vessels were charged with $30 \mathrm{~g}$ of $\mathrm{CO}_{2}$, which produced a gauge pressure of approximately $600 \mathrm{psi}$. The vessels were heated to $150^{\circ} \mathrm{C}$ and topped off with nitrogen gas to achieve a final total pressure of 2,500 psi.

\subsubsection{Laboratory Setup for High-Pressure Experiment}

Figure 2-1 is a schematic diagram showing the major pressure vessel components used in the experiment. Figure 2-2 shows a picture of the actual pressure vessels used in the experiments. A set of four 
Table 2-3. Actual Composition of Brines Solutions used in Experiments

\begin{tabular}{|c|c|c|c|c|}
\hline Analyte & $\begin{array}{c}\text { Brine } \\
\text { Solution \#1 }\end{array}$ & $\begin{array}{c}\text { Brine } \\
\text { Solution \#2 }\end{array}$ & $\begin{array}{c}\text { Brine } \\
\text { Solution \#3 }\end{array}$ & $\begin{array}{c}\text { Brine } \\
\text { Solution \#4 }\end{array}$ \\
\hline \multicolumn{5}{|c|}{ Anions } \\
\hline Alkalinity & 23 & 18 & 29 & ND \\
\hline Chloride & 61,200 & 1,025 & 750 & ND \\
\hline Sulfate & 1,080 & 900 & 975 & ND \\
\hline \multicolumn{5}{|c|}{ Cations } \\
\hline Aluminum & BDL & 0.00 & 0.00 & BDL \\
\hline Arsenic & 0.26 & 0.37 & 0.33 & 0.37047 \\
\hline Barium & 0.28 & 0.29 & 0.10 & 0.1068 \\
\hline Calcium & 7,840 & 9,400 & 8,540 & 8,829 \\
\hline Chromium & 0.04 & 0.03 & 0.02 & 0.01705 \\
\hline Cobalt & 0.02 & 0.01 & 0.01 & 0.01139 \\
\hline Copper & 0.29 & 0.33 & 0.28 & 0.246 \\
\hline Iron & 0.17 & 0.21 & 0.22 & 0.27841 \\
\hline Lead & 0.02 & 0.01 & 0.00 & BDL \\
\hline Magnesium & $1,285.89$ & 1,310 & 1,280 & $1,356.10$ \\
\hline Manganese & 0.02 & 0.01 & 0.00 & 0.01061 \\
\hline Nickel & 0.09 & 0.06 & 0.05 & 0.0597 \\
\hline Phosphorus & 0.04 & 0.00 & 0.00 & BDL \\
\hline Potassium & 793.87 & 987 & 1,500 & 1093.19 \\
\hline Scandium & 0.01 & 0.00 & 0.00 & 0.0052 \\
\hline Silicon & 1.14 & 0.85 & 0.86 & 0.70507 \\
\hline Sodium & 22,666 & 24,300 & 23,000 & 23,014 \\
\hline Strontium & 5.06 & 4.75 & 142.00 & 153.38 \\
\hline Tin & 0.00 & 0.01 & 0.00 & BDL \\
\hline Titanium & 17.27 & 16.90 & 15.30 & 18.54 \\
\hline Vandium & 0.43 & 0.31 & 0.28 & 0.44 \\
\hline Yttrium & 0.00 & 0.01 & 0.00 & 0.00 \\
\hline Zinc & 0.16 & 0.07 & 0.06 & 0.06 \\
\hline Zirconium & 0.00 & 0.00 & 0.00 & BDL \\
\hline \multicolumn{5}{|c|}{ Water Quality Parameters } \\
\hline $\mathrm{pH}$ & ND & 7.31 & 8.24 & ND \\
\hline ORP $(\mathrm{mV})$ & ND & 220.1 & 193.2 & ND \\
\hline
\end{tabular}

$\mathrm{BDL}=$ Below detection limit.

$\mathrm{ND}=$ Not determined.

ORP = Oxidation-reduction potential.

Brine \#1 used in Experiments 1, 2, and for slabs in Experiment 3.

Brine \#2 used in Experiment 3 for Anorthite and Glauconite.

Brine \#3 used in Experiment 4.

Brine \#4 used in Experiment 5, but has not been analyzed.

high-pressure experiments was initially prepared in Battelle's laboratory. During the reporting period at least four additional reaction vessels were procured at Battelle's expense to expedite execution of a larger number of experiments. This included some refinements in the experimental setup, construction of temperature and pressure control units, and a station to vibrate five vessels simultaneously. Chemically inert PTFE-Teflon ${ }^{\mathrm{TM}}$ liners were machined to vessel dimensions and inserted into the Hasteloy-C vessels to eliminate potential interactions between the study contents and the vessel walls. A varying mass of ground rock or slabs was placed into each liner and 275 or $300 \mathrm{~mL}$ of synthetic brine were added. Table 2-4 lists the compositions of all the experiments initiated or completed by October 2000. 


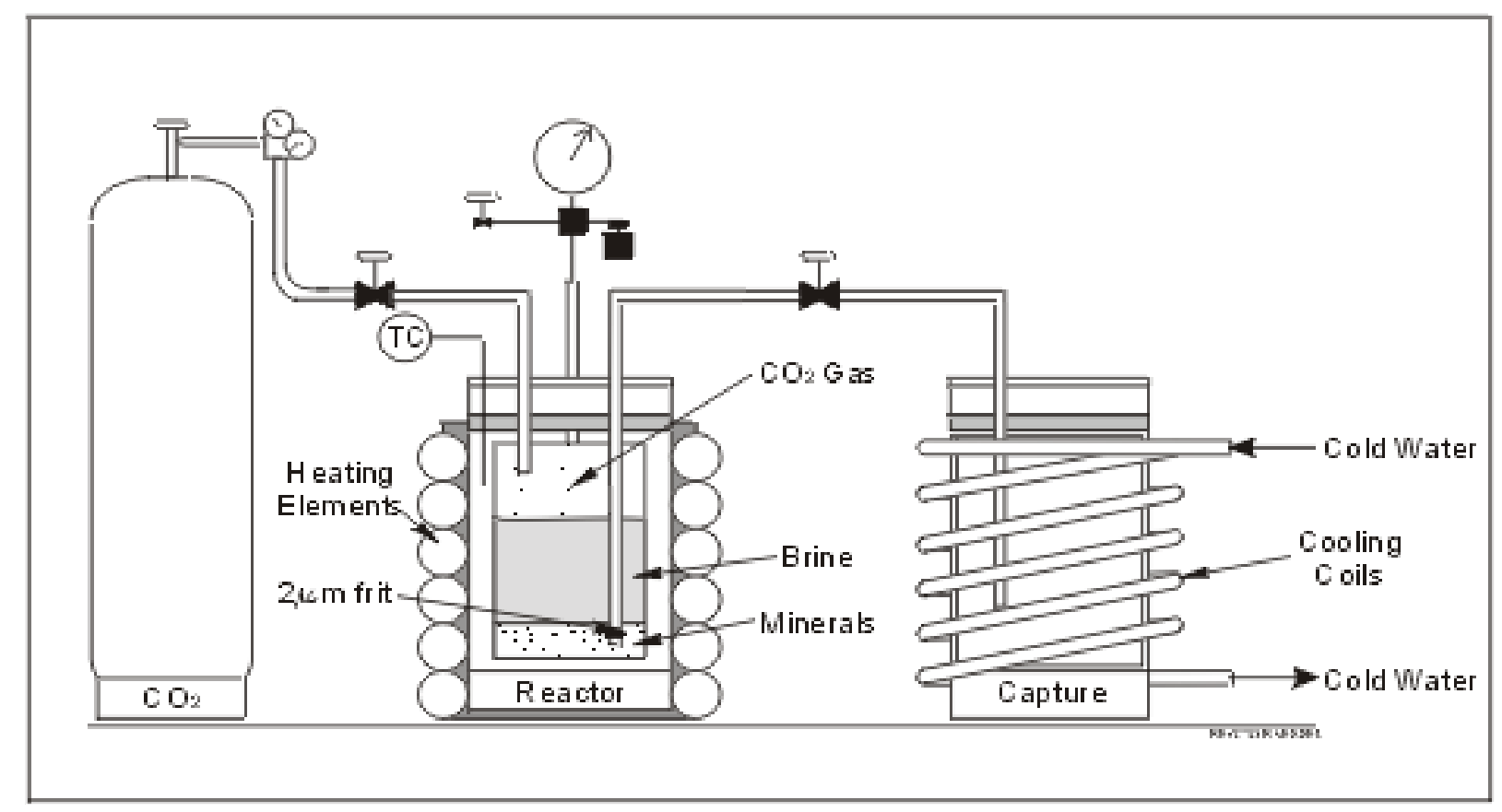

Figure 2-1. Schematic Drawing of Pressure Vessel

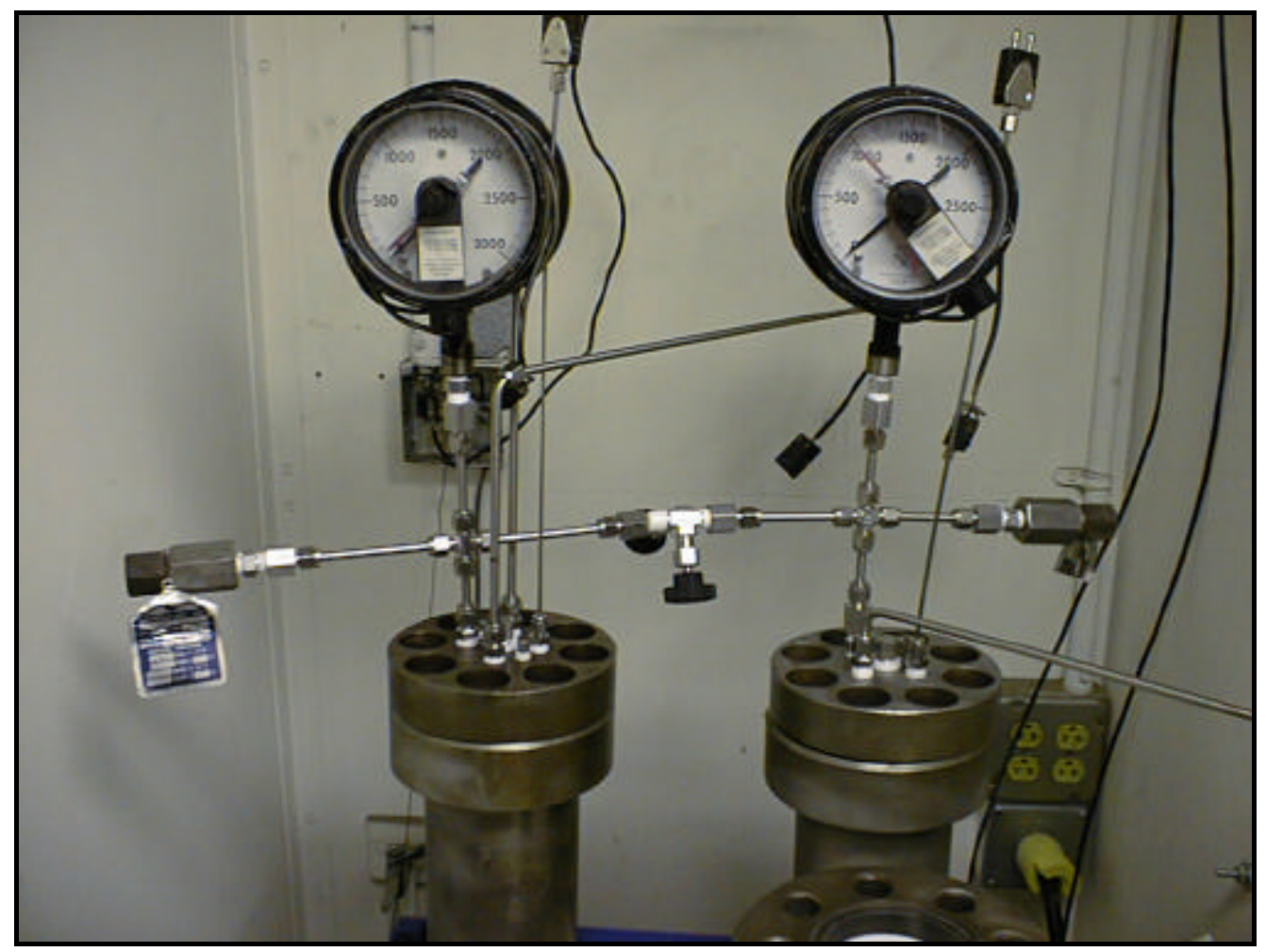

Figure 2-2. Photograph Showing Pressure Vessels Used In Experiments 
Table 2-4. Composition of Experiments

\begin{tabular}{||c|c|c|c|c|c||}
\hline Experiment No. & Core No. & $\begin{array}{c}\text { Core Depth } \\
(\mathbf{f t})\end{array}$ & $\begin{array}{c}\text { Mass of } \\
\text { Solid (g) }\end{array}$ & $\begin{array}{c}\text { Volume of Brine } \\
\text { Solution }(\mathbf{m L})\end{array}$ & $\begin{array}{c}\text { Mass of } \\
\mathbf{C O}_{\mathbf{2}} \text { (g) }\end{array}$ \\
\hline \hline 1A & 2,843 & 2,974 & 71.1 & 275 & 30 \\
1B & 2,843 & 2,980 & 66.7 & 275 & 30 \\
1C & 2,843 & 2,985 & 34.1 & 275 & 30 \\
1D & 2,958 & $5,532.3$ & 38.4 & 275 & 30 \\
2A & 2,838 & 5,580 & 94.56 & 300 & 30 \\
2B & Glauconite & NA & 81.82 & 300 & 30 \\
2C & Anorthite & $3,967.3$ & 80.77 & 300 & 30 \\
2D & TBS Well 149 & 3,071 & 1.9576 & 300 & 30 \\
3F & 645 & 3,140 & 2.2233 & 300 & 100 \\
3D & 645 & NA & 1.262 & 300 & 100 \\
3A & Anorthite & 5,580 & 1.0363 & 300 & 100 \\
3C & 2,838 & 5,911 & 2.3348 & 300 & 100 \\
3E & 2,838 & $3,967.3$ & 0.5617 & 300 & 100 \\
3B & TBS Well 149 & 78.0158 & 300 & 100 \\
3G & Anorthite & NA & 76.8925 & 300 & 100 \\
3H & Glauconite & 3,071 & 44.59 & 275 & 30 \\
4A & 645 & 3,140 & 44.46 & 275 & 30 \\
4B & 645 & 3,379 & 45.14 & 275 & 30 \\
4C & 779 & 2,726 & 25.88 & 275 & 30 \\
4D & 2,580 & NA & $50 / 30$ & 275 & 30 \\
5A & Anorthite/Kaolinite & NA & $50 / 50$ & 275 & 30 \\
5B & Anorthite/Montmorillonite & \multicolumn{3}{|r||}{} \\
\hline
\end{tabular}

A small amount of sodium sulfite was added immediately before closing each vessel to scavenge residual oxygen. After attaching tubing and instrumentation, each vessel was pressurized with high-purity nitrogen gas to detect leaks. As there were no problems with leakage, the vessels were charged with $30 \mathrm{~g}$ of $\mathrm{CO}_{2}$, which produced a gauge pressure of approximately $600 \mathrm{psi}$. The vessels were heated and topped off with nitrogen gas or $\mathrm{CO}_{2}$ gas to achieve a final total pressure of 2,000 or 2,500 psi. Sensors to monitor pressure and temperature were connected and the vessels were placed on a shaker table to agitate the mixtures periodically, while the mineral matter, brine, and $\mathrm{CO}_{2}$ equilibrated.

Special safety measures are planned for experiments involving $\mathrm{SO}_{2}$ gas due to its hazardous properties. These include additional safety training for staff, use of $\mathrm{SO}_{2}$ monitors, conduct of experiments in a specially ventilated room, and use of personal protection equipment during experiment setup and sampling. These experiments are planned for October/November 2000 start.

\subsubsection{Analytical Procedures}

The experiments ran for a period ranging from 30 to 60 days. At the end of the reaction time, the solid and solution phases were separated and analyzed along with a sample of the gas in the pressure vessel. Table 2-5 lists the analytes of interest for brine samples and standard methods for obtaining these results. The solution was analyzed for total organic carbon (TOC), alkalinity, $\mathrm{pH}$, ORP, sulfate, chloride, and metals. The solution analysis was compared with results from the unreacted brine solution. The solids were dried and analyzed in the same manner as the unreacted samples for comparison. Solid phases were analyzed using scanning electron microscopy (SEM) and energy dispersive spectroscopy (EDS). These techniques are generally quite useful, but they are limited to measuring the bulk properties of a solid. 
Table 2-5. Analytical Methods for Brine Solutions

\begin{tabular}{|c|c|c|c|c|c|}
\hline Parameter & $\begin{array}{l}\text { Analysis } \\
\text { Method } \\
\end{array}$ & $\begin{array}{l}\text { Sample } \\
\text { Volume }\end{array}$ & $\begin{array}{c}\text { Storage } \\
\text { Container }\end{array}$ & Preservation & $\begin{array}{c}\text { Sample Holding } \\
\text { Time } \\
\end{array}$ \\
\hline $\mathrm{pH}$ & Electrode & None & None & None & None \\
\hline ORP & Electrode & None & None & None & None \\
\hline Temperature & Thermometer & None & None & None & None \\
\hline TOC & EPA Method 5310 & $3 \mathrm{~mL}$ & Tedlar $^{\mathrm{TM}}$ bag & None & $28 \mathrm{~d}$ \\
\hline \multicolumn{6}{|c|}{ Cations } \\
\hline $\begin{array}{l}\text { K, Na, Ca, Mg, Si, Al, } \\
\text { Fe, Ti, Sr, V, Cr, Mn, } \\
\mathrm{Co}, \mathrm{Ni}, \mathrm{Cu}, \mathrm{Zn}, \mathrm{Ba}, \mathrm{Pb}\end{array}$ & $\begin{array}{c}\text { ICP/MS based on } \\
\text { EPA Method } 200.7\end{array}$ & $100 \mathrm{~mL}$ & Polyethylene & $\begin{array}{c}\text { Filter, } 4^{\circ} \mathrm{C}, \\
\mathrm{pH}<2 \\
\left(\mathrm{HNO}_{3}\right)\end{array}$ & $180 \mathrm{~d}$ \\
\hline \multicolumn{6}{|c|}{ Anions } \\
\hline $\mathrm{SO}_{4}, \mathrm{Cl}$ & EPA Method 300.0 & $100 \mathrm{~mL}$ & Polyethylene & $4^{\circ} \mathrm{C}$ & $7 \mathrm{~d}$ \\
\hline Alkalinity & EPA Method 310.1 & $100 \mathrm{~mL}$ & Polyethylene & $4^{\circ} \mathrm{C}$ & $14 \mathrm{~d}$ \\
\hline
\end{tabular}

EPA = U.S. Environmental Protection Agency.

$\mathrm{ICP} / \mathrm{MS}$ = Inductively-coupled plasma/mass spectrometry.

In most cases, the bulk changes in mineralogy are not significant during the timeframe of these experiments. Therefore, additional characterization is being performed using surface analytical techniques. For example, x-ray photoelectron spectroscopy (XPS) and Auger spectroscopy (collectively referred to as electron spectroscopy for chemical analysis, or ESCA) can be used to examine the top $100 \AA$ of solid surfaces. ESCA can be used to measure elemental concentrations at the surface of mineral grains. In addition, subtle differences in chemical bonding (chemical shift) can be identified, which may be interpreted as precursors to phase transformation. ESCA can be particularly useful for determining whether degradation is occurring at mineral surfaces, or if carbonate precipitation is taking place, as a result of the interaction between $\mathrm{CO}_{2}$ and the rock sample.

Additional insights into techniques for detecting subtle mineralogical changes were suggested by Dr. Sam Traina of the Ohio State University, in a meeting with Battelle personnel. Based on suggestions by Dr. Traina, Battelle will investigate the possibility of using photoemission spectroscopy, laser ablation spectroscopy, extended x-ray absorption fine structure (EXAFS), and secondary ion mass spectrometry (SIMS). Battelle plans to continue meeting with Dr. Traina, a leading expert in geochemistry, in an advisory role.

\subsection{Engineering and Economic Assessment}

The field application of $\mathrm{CO}_{2}$ sequestration is a very complex process involving detailed characterization, design, environmental permitting, and construction and drilling. It requires a large interdisciplinary team of scientists and engineers in addition to support from numerous other professionals. One of the tasks in the current project involves preparation of an engineering and economic assessment report. This report can help in planning and evaluating a pilot- or full-scale $\mathrm{CO}_{2}$ sequestration project for deep saline formations. Activities conducted under this task include a review of the status of existing technologies that could be used for $\mathrm{CO}_{2}$ sequestration, development of a preliminary engineering concept for accomplishing the required operations, and estimation of costs for sequestration systems. The primary components of the $\mathrm{CO}_{2}$ sequestration system considered are

- Capture of the $\mathrm{CO}_{2}$ from the flue gas

- Preparation of the $\mathrm{CO}_{2}$ for transportation (compression and drying)

- Transportation of the $\mathrm{CO}_{2}$ through a pipeline

- Injection of the $\mathrm{CO}_{2}$ into a suitable aquifer

- Subsurface and surface monitoring of the injection system. 
Costs are being estimated for sequestration of $\mathrm{CO}_{2}$ from the following three types of power plants:

- Pulverized coal with flue gas desulphurization (PC/FGD)

- Pulverized coal without flue gas desulphurization (PC)

- Intergrated coal gasification combined cycle (IGCC).

The sensitivity of cost to a variety of transportation and injection scenarios is also being studied. The scenarios used are indicated in Table 2-6 ( $\mathrm{Y}$ indicates a cost estimate was prepared; $\mathrm{N}$ indicates a cost estimate was not prepared).

Table 2-6. Cases Used to Explore Cost Sensitivity of Transportation/Sequestration

\begin{tabular}{||c|c|c|c|c|c||}
\hline \hline \multirow{2}{*}{$\begin{array}{c}\text { Well } \\
\text { Depth } \\
(\mathbf{m} / \mathbf{f t})\end{array}$} & $\begin{array}{c}\mathbf{1 5} \mathbf{~ k m}(\mathbf{9 . 3} \mathbf{~ m i}) \\
\text { and Normal } \\
\text { Terrain }\end{array}$ & $\begin{array}{c}\mathbf{1 5} \mathbf{~ k m}(\mathbf{9 . 3} \mathbf{~ m i}) \\
\text { and Urban } \\
\text { Terrain }\end{array}$ & $\begin{array}{c}\mathbf{1 5} \mathbf{~ k m}(\mathbf{9 . 3} \mathbf{m i}) \\
\text { and Hilly } \\
\text { Terrain }\end{array}$ & $\begin{array}{c}\mathbf{1 0 0} \mathbf{~ k m ~ ( 6 2 . 1 ~} \mathbf{~ m i}) \\
\text { and Normal } \\
\text { Terrain }\end{array}$ & $\begin{array}{c}\mathbf{4 0 0} \mathbf{~ k m ~ ( 2 4 9} \mathbf{~ m i}) \\
\text { and Normal } \\
\text { Terrain }\end{array}$ \\
\hline \hline $1,000 / 3,281$ & $\mathrm{Y}$ & $\mathrm{N}$ & $\mathrm{N}$ & $\mathrm{N}$ & $\mathrm{N}$ \\
\hline $2,000 / 6,562$ & $\mathrm{Y}$ & $\mathrm{Y}$ & $\mathrm{Y}$ & $\mathrm{Y}$ & $\mathrm{Y}$ \\
\hline $3,000 / 9,843$ & $\mathrm{Y}$ & $\mathrm{N}$ & $\mathrm{N}$ & $\mathrm{N}$ & $\mathrm{N}$ \\
\hline \hline
\end{tabular}

\subsection{Other Activities}

During the period covered by this report, several other activities were undertaken. Most significantly, two papers were presented on the geochemical and hydrogeologic issues related to $\mathrm{CO}_{2}$ sequestration in deep saline formations at the 5th International Conference on Greenhouse Gas Control Technologies at Cairns, Australia. The detailed manuscripts for these presentations have been submitted for publication in the conference proceedings. Two abstracts related to the current project were submitted for presentation at the NETL conference in May 2001. A detailed briefing about Battelle's project was presented at a workshop at NETL in July 2000. Finally, Battelle interacted with stakeholders such as American Electric Power, BP, and Electric Power Research Institute to update them on the status of the research. 


\subsection{RESULTS OF EXPERIMENTS}

The following sections present preliminary results and discussion for the experiments conducted to date. These results should be considered preliminary at this time. More detailed evaluation of the experimental results and comparison with geochemical simulations will be included in the final technical report for Phase II.

\subsection{Results of Batch Experiments}

Results of the solution analysis, including alkalinity, pH, ORP, sulfate, chloride, and metals, for Experiments 2 and 3 are shown in Tables 3-1 and 3-2 respectively. The composition of the unreacted brine

Table 3-1. Concentrations of Dissolved Species $(\mathrm{mg} / \mathrm{L})$ in Brine after Reaction with Rock Samples for Experiment 2

\begin{tabular}{|c|c|c|c|c|c|}
\hline Sample ID & $\begin{array}{c}2 \mathrm{~A} \\
\text { Core } 2,838 \\
\end{array}$ & $\begin{array}{c}\text { 2B } \\
\text { Glauconite }\end{array}$ & $\begin{array}{c}2 \mathrm{C} \\
\text { Anorthite }\end{array}$ & \begin{tabular}{|c|} 
2D \\
TBS Well 149 \\
\end{tabular} & Brine Solution \\
\hline Depth (ft) & $\mathbf{5 , 5 8 0}$ & NA & NA & \begin{tabular}{|c|}
$3,967.3$ \\
\end{tabular} & \\
\hline \multicolumn{6}{|c|}{ Anions } \\
\hline Alkalinity & 1,230 & 327 & 630 & 623 & 23 \\
\hline Chloride & 22,800 & 60,100 & 69,100 & 65,900 & 61,200 \\
\hline Sulfate & 875 & 1,825 & 1,300 & 1,050 & 1,080 \\
\hline \multicolumn{6}{|c|}{ Cations } \\
\hline Aluminum & 24.00 & 1.46 & 1.31 & 0.48 & BDL \\
\hline \begin{tabular}{|l|} 
Arsenic \\
\end{tabular} & 0.12 & 0.58 & 0.63 & 0.48 & 0.26 \\
\hline Barium & 0.58 & 0.45 & 0.34 & 1.06 & 0.28 \\
\hline Calcium & 2,621 & 10,369 & 10,004 & 10,295 & 7,840 \\
\hline Chromium & 0.48 & 0.06 & 0.20 & 0.06 & 0.04 \\
\hline Cobalt & 0.87 & 0.92 & 1.24 & 1.52 & 0.02 \\
\hline Copper & 0.31 & 0.28 & 0.74 & 0.36 & 0.29 \\
\hline Iron & 52.12 & 4.59 & 19.38 & 64.63 & 0.17 \\
\hline Lead & 0.11 & 0.00 & 0.07 & 0.00 & 0.02 \\
\hline Magnesium & 1,000 & 1,873 & 1,568 & 1,471 & $1,285.89$ \\
\hline Manganese & 1.47 & 22.81 & 1.17 & 3.00 & 0.02 \\
\hline Nickel & 229.07 & 6.41 & 8.39 & 3.74 & 0.09 \\
\hline Phosphorus & 1.15 & 0.27 & 0.03 & 0.01 & 0.04 \\
\hline Potassium & 535 & 2,493 & 1,003 & 1,060 & 793.87 \\
\hline Scandium & 0.03 & 0.01 & 0.01 & 0.00 & 0.01 \\
\hline Silicon & 137.51 & 31.95 & 30.75 & 29.50 & 1.14 \\
\hline Sodium & 9,654 & 28,794 & 30,811 & 28,175 & 22,666 \\
\hline Strontium & 2.40 & 6.92 & 6.42 & 12.82 & 5.06 \\
\hline Tin & 0.01 & 0.00 & 0.01 & 0.00 & 0.00 \\
\hline Titanium & 12.47 & 16.96 & 19.06 & 16.48 & 17.27 \\
\hline Vandium & 0.19 & 0.42 & 0.39 & 0.39 & 0.43 \\
\hline Yttrium & 0.03 & 0.01 & 0.00 & 0.00 & 0.00 \\
\hline Zinc & BDL & 0.90 & 0.36 & 0.09 & 0.16 \\
\hline Zirconium & 0.02 & 0.00 & 0.00 & 0.01 & 0.00 \\
\hline \multicolumn{6}{|c|}{ Water Quality Parameters } \\
\hline $\mathrm{pH}$ & 7.03 & 6.28 & 6.11 & 5.82 & ND \\
\hline ORP $(\mathrm{mV})$ & -33.2 & -70.9 & 42.1 & 70.1 & ND \\
\hline
\end{tabular}


Table 3-2. Concentrations of Dissolved Species (mg/L) in Brines after Reaction with Rock Samples for Experiment 3

\begin{tabular}{|c|c|c|c|c|c|c|}
\hline Sample ID & $\begin{array}{c}3 \mathrm{~A}, 3 \mathrm{~B}, \text { and } 3 \mathrm{C} \\
\text { Slabs \#1 }\end{array}$ & $\begin{array}{c}\text { 3D, 3E, and } 3 \mathrm{~F} \\
\text { Slabs \#2 }\end{array}$ & $\begin{array}{c}\text { 3G } \\
\text { Anorthite \#2 }\end{array}$ & $\begin{array}{c}3 \mathrm{H} \\
\text { Glauconite \#2 }\end{array}$ & $\begin{array}{c}\text { Brine } \\
\text { Solution \#2 }\end{array}$ & $\begin{array}{c}\text { Brine } \\
\text { Solution \#3 }\end{array}$ \\
\hline \multicolumn{7}{|c|}{ Anions } \\
\hline Alkalinity & 760 & 200 & 610 & $<1$ & 18 & 29 \\
\hline Chloride & 57,000 & 65,500 & 1,175 & 1,050 & 1,025 & 750 \\
\hline Sulfate & 500 & 205 & 600 & 1,650 & 900 & 975 \\
\hline \multicolumn{7}{|c|}{ Cations } \\
\hline Aluminum & 0.39 & 0.22 & BDL & 0.00 & 0.00 & 0.00 \\
\hline Arsenic & 0.40 & 0.42 & 0.55 & 0.37 & 0.37 & 0.33 \\
\hline Barium & 0.47 & 0.39 & 0.67 & 0.30 & 0.29 & 0.10 \\
\hline Calcium & 17,600 & 17,100 & 6,319 & 9,650 & 9,400 & 8,540 \\
\hline Chromium & 0.10 & 0.13 & 0.06 & 0.04 & 0.03 & 0.02 \\
\hline Cobalt & 0.57 & 0.43 & 0.23 & 0.01 & 0.01 & 0.01 \\
\hline Copper & 0.80 & 1.05 & 1.34 & 0.32 & 0.33 & 0.28 \\
\hline Iron & 61.20 & 111.00 & 117.88 & 0.23 & 0.21 & 0.22 \\
\hline Lead & 0.06 & 0.04 & 0.35 & 0.01 & 0.01 & 0.00 \\
\hline Magnesium & 1,430 & 1,640 & 5,560 & 1,390 & 1,310 & 1,280 \\
\hline Manganese & 2.71 & 1.93 & 3.87 & 0.01 & 0.01 & 0.00 \\
\hline Nickel & 28.10 & 23.70 & 5.82 & 0.06 & 0.06 & 0.05 \\
\hline Phosphorus & BDL & BDL & BDL & 0.00 & 0.00 & 0.00 \\
\hline Potassium & 870 & 1,480 & 1,630 & 987 & 987 & 1,500 \\
\hline Scandium & 0.04 & 0.03 & 0.07 & 0.01 & 0.00 & 0.00 \\
\hline Silicon & 65.40 & 41.70 & 161.81 & 0.93 & 0.85 & 0.86 \\
\hline Sodium & 24,100 & 26,500 & 31,755 & 24,200 & 24,300 & 23,000 \\
\hline Strontium & 5.32 & 176.00 & 120.69 & 4.65 & 4.75 & 142.00 \\
\hline Tin & BDL & BDL & BDL & 0.02 & 0.01 & 0.00 \\
\hline Titanium & 19.90 & 19.60 & 15.95 & 17.00 & 16.90 & 15.30 \\
\hline Vandium & 0.36 & 0.41 & 0.57 & 0.29 & 0.31 & 0.28 \\
\hline Yttrium & 0.01 & 0.00 & 0.00 & 0.01 & 0.01 & 0.00 \\
\hline Zinc & 0.42 & 0.42 & 5.97 & 0.07 & 0.07 & 0.06 \\
\hline Zirconium & 0.00 & 0.01 & 0.01 & 0.01 & 0.00 & 0.00 \\
\hline \multicolumn{7}{|c|}{ Water Quality Parameters } \\
\hline $\mathrm{pH}$ & 5.97 & 6.22 & 6.28 & 5.35 & 7.31 & 8.24 \\
\hline ORP $(\mathrm{mV})$ & 25.9 & -17.9 & -73.6 & 69 & 220.1 & 193.2 \\
\hline
\end{tabular}

is also shown in these tables for comparison with the reacted mixtures. Relative to their initial composition, the solutions analyzed at the end of the experiments were more concentrated in dissolved species, overall. The net increase in total dissolved solids could be due to any of three factors: (1) dissolution of soluble salts that were not removed by rinsing the ground material before the tests were begun; (2) dissolution of mineral matter (primarily silicates, but may include carbonates and sulfate minerals) during the experiment; and (3) reduction in the water content as a result of evaporation from the reactor.

It is important to note that the measured alkalinity and $\mathrm{pH}$, given in Tables 3-1 and 3-2, may not be representative of conditions while the experiment was in progress. This is because the pressure drop upon decanting the solution causes dissolved $\mathrm{CO}_{2}$ to volatilize and causes the distribution of carbon species in solution to change accordingly. 
Results of vapor phase analysis by gas chromatography are shown in Table 3-3 for experiments completed by October 2000. These results have been normalized to 100\%. The vapor consists of approximately $20 \% \mathrm{CO}_{2}$ and $80 \% \mathrm{~N}_{2}$ for Experiment 2. In Experiment 3 the vapor consists of approximately $95 \% \mathrm{CO}_{2}$ and $5 \% \mathrm{~N}_{2}$. The $\mathrm{O}_{2}$ content was negligible, presumably due to precautions taken to exclude oxygen from the system. The gas composition data were used to model the solution and thereby deduce the amount of dissolved $\mathrm{CO}_{2}$ in the liquid phase.

Table 3-3. Composition of Gas Phase at End of Experiments (\% by Volume)

\begin{tabular}{|c|c|c|c|c|c|}
\hline Experiment No. & Core No./Sample Name & Depth (ft) & $\% \mathrm{CO}_{2}$ & $\% \mathrm{O}_{2}$ & $\% \mathrm{~N}_{2}$ \\
\hline $1 \mathrm{~A}$ & Core No. 2,843 & 2,974 & 21.3 & ND & 78.99 \\
\hline $1 \mathrm{~B}$ & Core No. 2,843 & 2,980 & 20.89 & ND & 78.16 \\
\hline $1 \mathrm{C}$ & Core No. 2,843 & 2,985 & 20.11 & ND & 79.03 \\
\hline $1 \mathrm{D}$ & Core No. 2,843 & $5,532.3$ & 17.15 & ND & 82.79 \\
\hline $2 \mathrm{~A}$ & Core No. 2,838 & 5,580 & 9.96 & 3.55 & 86.48 \\
\hline $2 \mathrm{~B}$ & Glauconite Specimen & NA & 20.31 & 1.37 & 78.32 \\
\hline $2 \mathrm{C}$ & Anorthite Specimen & NA & 21.02 & 1.12 & 77.86 \\
\hline $2 \mathrm{D}$ & TBS Well 149 & $3,967.3$ & 18.99 & 1.68 & 79.33 \\
\hline $3 \mathrm{~A}, 3 \mathrm{~B}$, and $3 \mathrm{C}$ & Slabs \#1 ${ }^{\text {(a) }}$ & NA & 96.93 & ND & 3.07 \\
\hline $3 \mathrm{D}, 3 \mathrm{E}$, and $3 \mathrm{~F}$ & Slabs \#2 $2^{(\mathrm{a})}$ & NA & 95.84 & ND & 4.16 \\
\hline $3 \mathrm{G}$ & Anorthite $^{(\mathrm{a})}$ & NA & 91.37 & 0.34 & 8.29 \\
\hline $3 \mathrm{H}$ & Glauconite $^{(a)}$ & NA & 94.95 & 1.94 & 3.11 \\
\hline $4 \mathrm{~A}$ & Core No. 645 & 3,071 & 44.19 & 0.97 & 54.84 \\
\hline 4B & Core No. 645 & 3,140 & 44.63 & 0.89 & 54.48 \\
\hline $4 \mathrm{C}$ & Core No. 779 & 3,379 & 84.24 & $\mathrm{ND}$ & 15.76 \\
\hline $4 \mathrm{D}$ & Core No. 2,580 & 2,726 & 62.78 & 0.80 & 36.42 \\
\hline $5 \mathrm{~A}$ & Anorthite/Kaolinite & NA & NA & NA & NA \\
\hline $5 \mathrm{~B}$ & Anorthite/Montmorillonite & NA & NA & NA & NA \\
\hline
\end{tabular}

(a) Only $\mathrm{CO}_{2}$ (g) was used in Experiment 3.

Values for $\mathrm{CO}_{2}, \mathrm{O}_{2}$, and $\mathrm{N}_{2}$ are normalized to $100 \%$.

Most of the rock and mineral samples have been analyzed for mineral identification by $\mathrm{x}$-ray diffraction (XRD) and chemical composition of rock samples by EDS. These results currently are being finalized and will be presented in the next technical report.

\subsection{Results of XPS Analysis}

Starting materials and reaction products were analyzed by XPS to determine whether surface composition changed as a result of the experiments. In XPS, binding energies of core shell electrons ejected by X-rays are used to identify compositional elements. XPS peaks in the spectra correspond to the abundance of atoms that emit photoelectrons, and are proportional to the concentration of elements in the surface region of the sample. Typically, these emissions account for the top 50 to $100 \AA$ of the surface. For example, the silicon $2 \mathrm{p}$ emission occurs at approximately $100 \mathrm{eV}$ in silicates. This energy can vary slightly due to the particular structure of the compound containing silicon. This "chemical shift" enables XPS to differentiate elements based on the local chemical environment and is a powerful technique for discerning the composition of a material.

Figure 3-1 compares an XPS spectrum for Anorthite with a spectrum obtained after reacting an Anorthite sample with $\mathrm{CO}_{2}$ and brine for 30 days at $150^{\circ} \mathrm{C}$. Specimens used for this analysis were produced in Experiments 2 and 3. In Figure 3-1, elements were identified according to the binding energy for each 


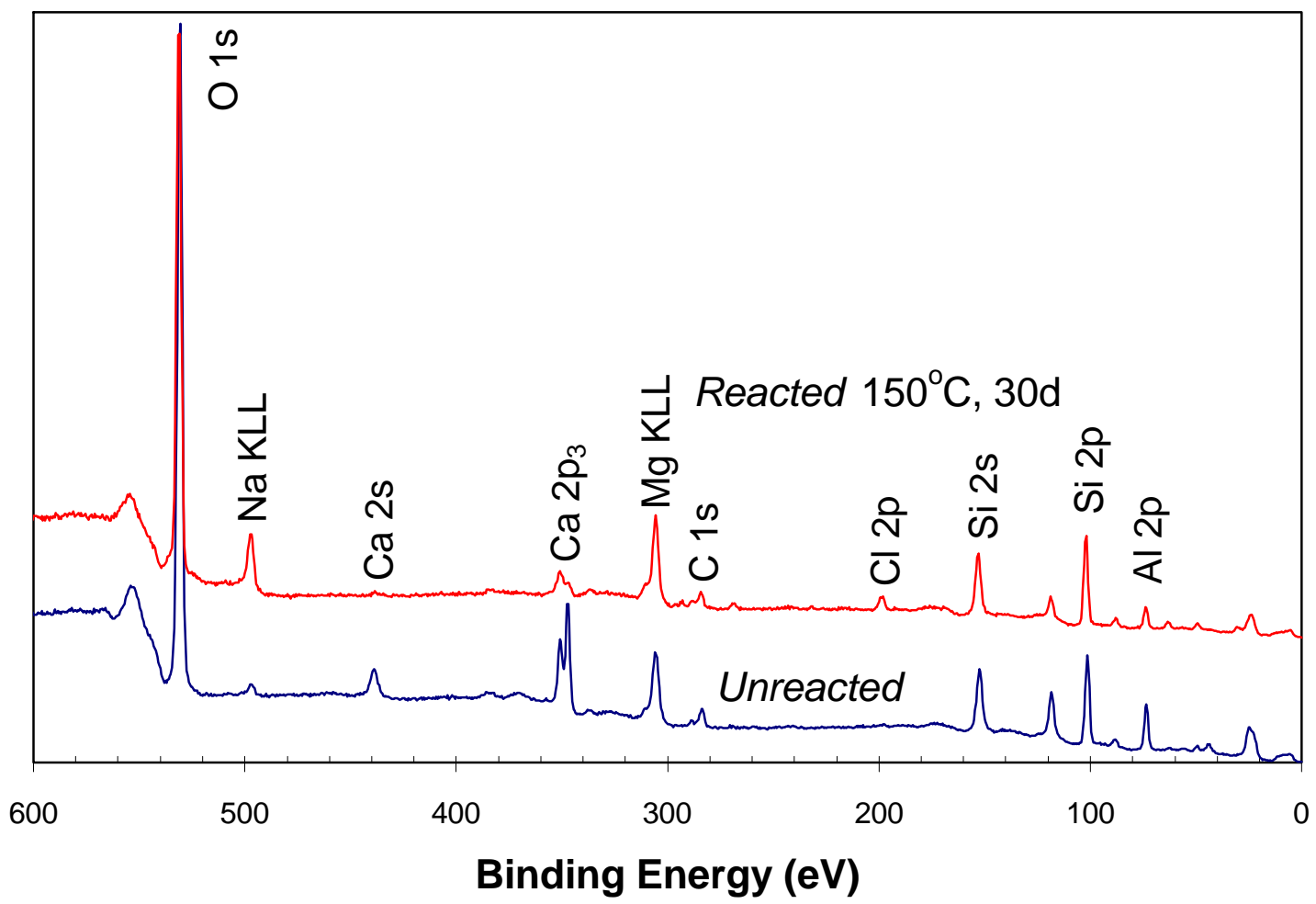

Figure 3-1. Portion of the XPS Spectrum for Unreacted and Reacted Anorthite

type of emission, which are labeled above the peaks. Peaks labeled $1 \mathrm{~s}$ and $2 \mathrm{p}$ are photoelectron emissions and peaks labeled KLL are Auger electron emissions. In this example, as with other analyses performed in this study, peak intensities (height or area) were used to calculate concentrations as percentages of the total intensity. A quantitative analysis based on Figure 3-1 is described in the following paragraphs.

Table 3-4 summarizes data for Anorthite prior to reaction, after reacting at $50^{\circ} \mathrm{C}$ for 30 days, and after reacting at $150^{\circ} \mathrm{C}$ for 30 days. Table $3-4$ also lists elemental percentages for ideal Anorthite of composition that is $90 \%$ Anorthite (calcium end member of the plagioclase feldspar series) and $10 \%$ albite (sodium end member), or $\mathrm{An}_{90}$. Terms in the brackets next to the element symbols indicate the photoelectron emission used in the XPS analysis. It can be seen that all of the Anorthite specimens contain 4 to $5 \%$ carbon. However, none of this carbon is in the carbonate form. Based on the binding energy of the carbon signal, this carbon is likely a hydrocarbon which could have sorbed onto particle surfaces from exposure to vacuum equipment. Other significant observations are as follows:

Table 3-4. Results of XPS Analysis of Anorthite in Percent Peak Area

\begin{tabular}{|c|c|c|c|c|c|c|c|c|c|c|}
\hline Sample & $\mathrm{C}[1 \mathrm{~s}]$ & $\mathrm{O}[1 \mathrm{~s}]$ & $\mathrm{Na}[\mathbf{1 s}]$ & $K[2 p]$ & $\operatorname{Mg}[1 \mathrm{~s}]$ & $\mathrm{Ca}[2 p]$ & $\mathbf{A l}[2 \mathbf{p}]$ & $\mathrm{Si}[2 \mathrm{p}]$ & $\mathrm{Cl}[2 \mathrm{p}]$ & $\mathrm{Fe}[2 \mathrm{p3}]$ \\
\hline Ideal $\mathrm{An}_{90}{ }^{(\mathrm{a})}$ & 0.00 & 61.54 & 0.77 & 0.00 & 0.00 & 6.92 & 14.62 & 16.15 & 0.00 & 0.00 \\
\hline Unreacted & 4.98 & 63.46 & 0.65 & 0.00 & 3.42 & 5.02 & 8.77 & 12.94 & 0.11 & 0.66 \\
\hline 30 day, $50^{\circ} \mathrm{C}$ & 3.80 & 64.47 & 3.18 & 0.02 & 1.29 & 2.62 & 10.54 & 12.00 & 1.73 & 0.35 \\
\hline 30 day, $150^{\circ} \mathrm{C}$ & 5.35 & 60.38 & 4.90 & 0.09 & 5.89 & 1.45 & 4.88 & 15.13 & 1.16 & 0.77 \\
\hline
\end{tabular}

(a) Calculated signal area. 
- The sodium concentration increased as a result of the experiments. The percentage increase of sodium was greater in the $150^{\circ} \mathrm{C}$ experiment than in the $50^{\circ} \mathrm{C}$ experiment, indicating that the extent of reaction is greater at higher temperature. Note that the sodium content of the unreacted material is close to the theoretical amount.

- Because an increase in sodium content could result from incomplete rinsing of brine from the reacted samples, chloride also was analyzed to determine if it behaved similar to sodium. Table 3-4 shows that chloride is slightly higher in the two reacted samples, indicating that the specimens may have had some residual brine, but the chloride content is several factors less than the increase in sodium. This result indicates that the increase in sodium cannot be entirely due to residual salt. Rather, the sodium appears to be incorporated into the structure of the feldspar.

- Calcium decreases with the extent of reaction, which is opposite to the trend for sodium. Figure 3-2 shows this trend in the form of bar graphs (percent values were recalculated after subtracting carbon and other impurities from the raw data). However, unlike sodium, the calcium content of the unreacted material is deficient in calcium.

- Two other components of feldspar are aluminum and silicon. The unreacted feldspar is deficient in aluminum and silicon, compared to the ideal composition. While there is a slight increase in aluminum after the $50^{\circ} \mathrm{C}$ run, the aluminum content decreases after the $150^{\circ} \mathrm{C}$ run. Conversely, silicon increases slightly following the $50^{\circ} \mathrm{C}$ run, and increases following the $150^{\circ} \mathrm{C}$ run. Figure 3-3 shows this trend in the form of bar graphs. The overall trend of decreasing aluminum and increasing silicon is consistent with a transition from Anorthite to albite.

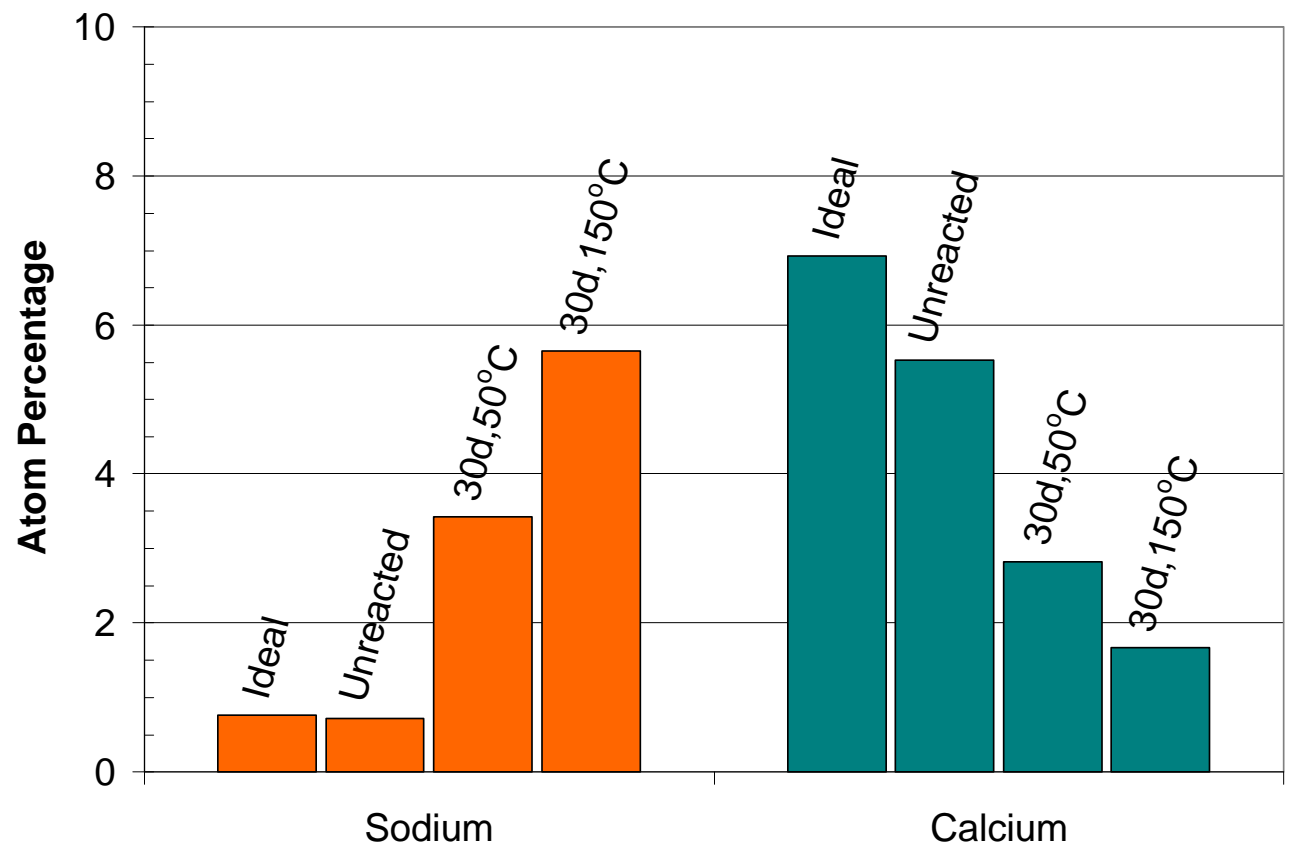

Figure 3-2. Concentrations of Sodium and Calcium for Ideal $\mathbf{A n}_{90}$ and Experimental Specimens 


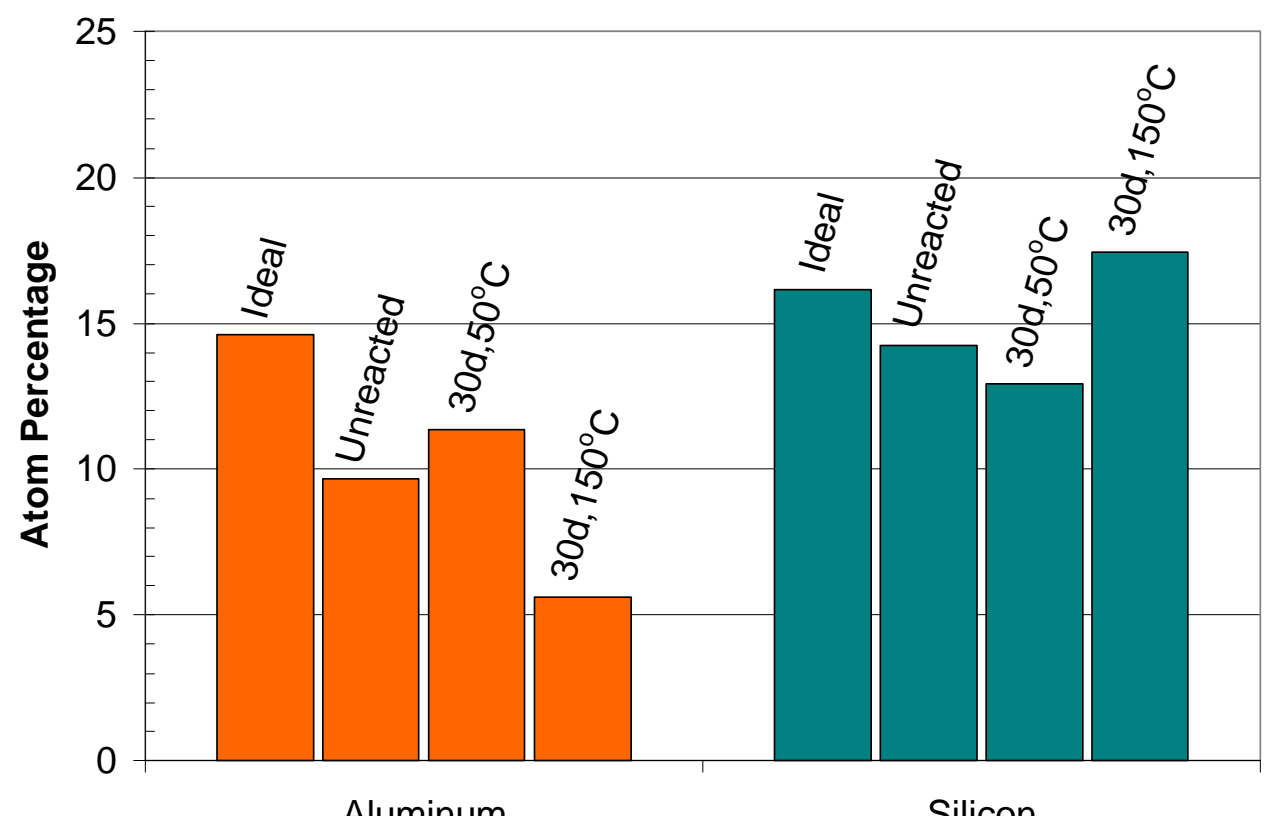

Figure 3-3. Concentrations of Aluminum and Silicon for Ideal $\mathbf{A n}_{90}$ and Experimental Specimens

The apparent inverse relationship between sodium and calcium was examined further by plotting the composition of the specimens against theoretical values for the anorthite-albite series. Figure 3-4 shows that the sodium content for the unreacted sample (square) falls on the theoretical curve for plagioclase at $91 \%$ Anorthite and $9 \%$ albite, or $\mathrm{An}_{91}$. In these plots, atomic percentages were recalculated without impurities

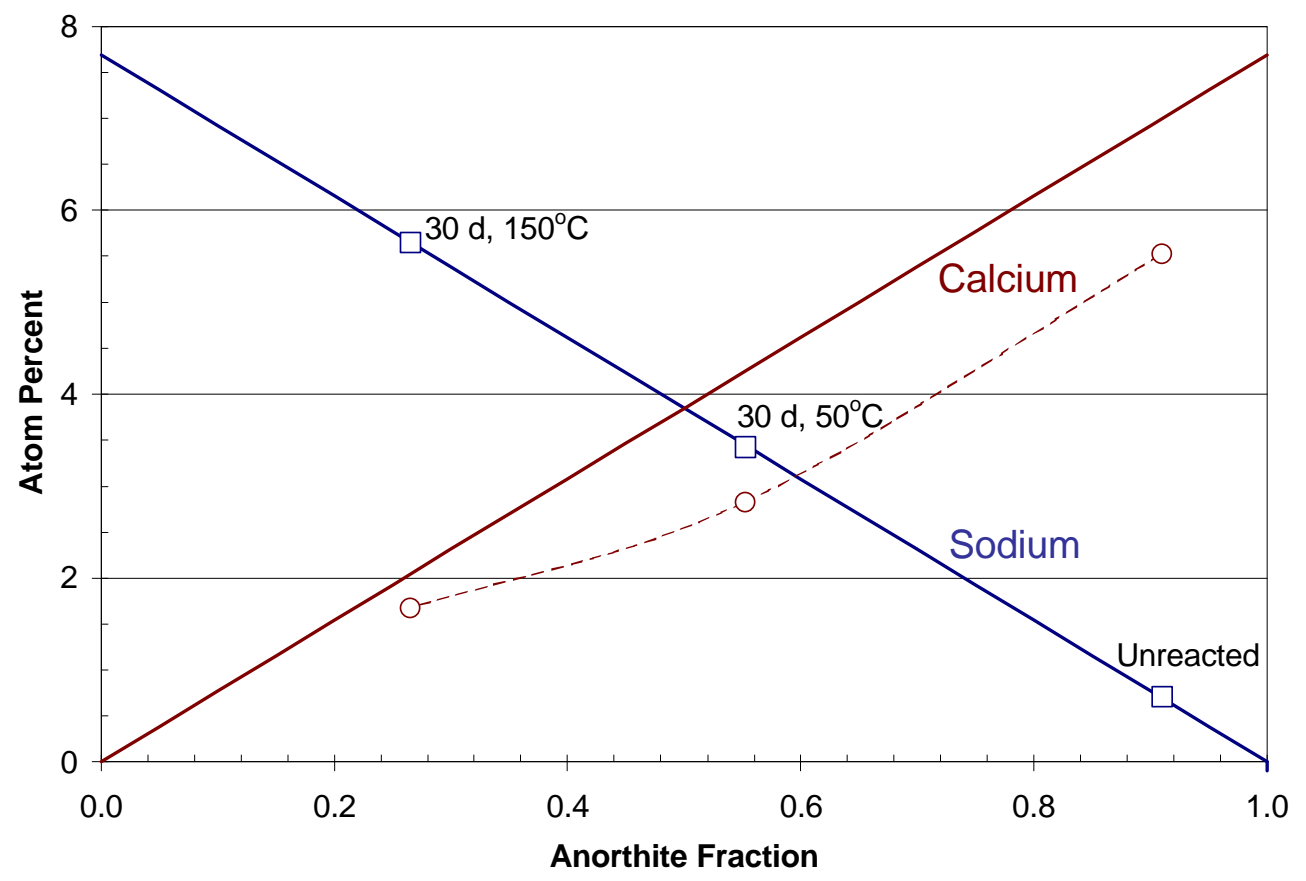

Figure 3-4. Anorthite Content Based on Sodium and Calcium Concentrations for an Ideal System (lines) and Experimental Specimens (symbols) 
such as carbon and chloride. When sodium concentrations for the reacted specimens are plotted on the theoretical curve the predicted composition is $\mathrm{An}_{55}$ for the sample equilibrated for 30 days at $50^{\circ} \mathrm{C}$, and $\mathrm{An}_{27}$ for the sample equilibrated for 30 days at $150^{\circ} \mathrm{C}$. Figure $3-4$ also shows that the three specimens were found to be deficient in calcium (circles) when compared to the ideal amounts. This deficiency may be due to partial replacement of calcium by iron and magnesium in the Anorthite structure. It can be seen that the calcium content is closest to the ideal amount when the greatest sodium substitution has taken place $\left(\mathrm{An}_{27}\right)$.

The behavior depicted in Figure 3-4 suggests that calcium in the feldspar was partially replaced by sodium during the experiments, and that the extent of replacement is enhanced by the higher reaction temperature. Calcium that is liberated due to the reaction is available for precipitating carbon species from solution in the form of calcium carbonate. However, no calcium carbonate was detected at the conclusion of these experiments. One explanation for the absence of calcium carbonate is that the $\mathrm{pH}$ of solution remained too low to stabilize a carbonate mineral. In a future experiment, kaolinite or smectite will be included with the Anorthite to raise the $\mathrm{pH}$ of solution and encourage precipitation of calcium carbonate.

Products of experimental runs consisting of Glauconite clay, brine and $\mathrm{CO}_{2}$ also were analyzed by XPS to detect compositional changes after the reaction. As the result of the analysis given in Table 3-5 shows, there were no substantive differences in composition between the starting Glauconite and that analyzed at the conclusion of the experiment. This indicates that experimental conditions were not conducive to reaction of Glauconite. Glauconite was chosen as a starting material for tests in this study because of the potential for iron to precipitate iron carbonate. In future experiments, a reducing environment will be maintained using $\mathrm{SO}_{2}$ gas, which may help increase the concentration of ferrous ions in solution and promote precipitation of iron carbonate.

Table 3-5. Results of XPS Analysis of Glauconite in Percent Peak Area

\begin{tabular}{|c|c|c|c|c|c|c|c|c|c|c|c|}
\hline Sample & $\mathrm{C}[1 \mathrm{~s}]$ & $\mathrm{O}[1 \mathrm{~s}]$ & $\mathrm{Na}$ [1s] & $\mathrm{Mg}[1 \mathrm{~s}]$ & $\mathrm{Al}[2 \mathrm{p}]$ & $\mathrm{Si}[2 p]$ & $\mathrm{Cl}[2 \mathrm{p}]$ & $\mathbf{K}[2 \mathbf{p}]$ & $\mathrm{Fe}[2 \mathrm{p3}]$ & $\mathrm{Ca}$ [2p] & $\mathbf{F}[\mathbf{1 s}]$ \\
\hline Unreacted & 1.11 & 67.49 & 0.2 & 2.79 & 3.46 & 17.03 & 0.05 & 2.86 & 3.92 & 0.98 & 0.11 \\
\hline 30 day, $150^{\circ} \mathrm{C}$ & 2.21 & 65.32 & 1.28 & 2.83 & 3.45 & 16.73 & 0.32 & 2.49 & 3.69 & 1.09 & 0.58 \\
\hline
\end{tabular}

\subsection{Preliminary Conclusions}

- XPS was a highly effective tool for measuring the surface composition of starting materials and reaction products.

- Different forms of carbon can be detected and quantified separately by XPS.

- In reactions involving anorthite, the percentage increase in sodium and concomitant decrease in calcium was greater in the $150^{\circ} \mathrm{C}$ experiment than in the $50^{\circ} \mathrm{C}$ experi ment, indicating that the extent of reaction is greater at higher temperature.

- The net loss of calcium in the feldspar experiments increased the calcium in solution, which can potentially react with carbonate species to form calcium carbonate solid. Future experiments will include kaolinite or smectite to increase solution $\mathrm{pH}$ and stabilize carbonate compounds. 
- Experiments with glauconite did not reveal changes in composition that would be conducive to forming iron carbonate. This result suggests that a reducing agent such as $\mathrm{SO}_{2}$ gas may be needed to produce ferrous ions and precipitate a carbonate compound. 


\subsection{FUTURE PLANS}

The experiments currently underway will be completed. The resulting fluid, gases, and rock samples will be characterized in detail as discussed above to determine the geochemical changes. The experimental results also will be compared with geochemical simulation results. Further experiments will be devised based on the insights gained from the ongoing tests. The composition and the duration of the experiments also will be determined by the remaining time for the project. It is likely that only one or two more set of experiments can be completed before the end of the experiments in Phase II.

The compilation of engineering and economic aspects will be finalized with further addition of cost details and preparation of the draft report.

\subsection{PROBLEMS AND REMEDIAL MEASURES}

No significant problems are anticipated at this time in meeting the overall project objectives.

\subsection{REFERENCES}

Bergman, P.D., and E.M. Winter. 1995. "Disposal of Carbon Dioxide in Aquifers in the U.S." Energy Conversion and Management, 36(6-9): 523-526.

Sass, B., N. Gupta, L. Smith, and E. Drescher. 1999. Experimental Evaluation of Chemical Sequestration of Carbon Dioxide in Deep Saline Formations. Phase I Topical Report. Prepared by Battelle for the U.S. Department of Energy, Federal Energy Technology Center, under DOE Contract No. DE-AC26-98FT40418. 